\title{
Trypanosoma cruzi in Triatomines and wild mammals in the National Park of Serra das Confusões, Northeastern Brazil
}

\author{
Andréa Pereira da Costa ${ }^{[1],[2], ~ J u l i a n a ~ I s a b e l ~ G i u l i ~ d a ~ S i l v a ~ F e r r e i r a ~}{ }^{[1]}$, \\ Ryan Emiliano da Silva ${ }^{[1]}$, Renata Tonhosolo ${ }^{[1]}$, Andreina de Carvalho Araújo ${ }^{[3]}$, \\ Maíra Freitas Guimarães ${ }^{[3]}$ Mauricio Cláudio Horta ${ }^{[3]}$, Marcelo Bahia Labruna ${ }^{[1]}$ \\ and Arlei Marcili ${ }^{[1],[4]}$
}

\begin{abstract}
[1]. Departamento de Medicina Veterinária Preventiva e Saúde Animal, Faculdade de Medicina Veterinária e Zootecnia, Universidade de São Paulo, São Paulo, SP, Brasil.

[2]. Programa de Pós-Graduação Stricto Sensu em Ciência Animal, Curso de Medicina Veterinária, Universidade Estadual do Maranhão, São Luis, MA, Brasil.

[3]. Faculdade de Medicina Veterinária, Universidade Federal do Vale do São Francisco, Petrolina, PE, Brasil.

[4]. Programa de Pós-Graduação em Medicina e Bem-Estar Animal, Universidade Santo Amaro, São Paulo, SP, Brasil.
\end{abstract}

\begin{abstract}
Introduction: The National Park of Serra das Confusões (NPSC) is a protected area of natural landscape located in Southern Piauí, Brazil, and it is considered as one of the largest and most important protected areas in the Caatinga biome. Methods: The natural occurrences of trypanosomatids from hemocultures on small mammals and cultures from intestinal contents triatomines were detected through molecular diagnoses of blood samples, and phylogenetic relationship analysis of the isolates parasites using the trypanosome barcode (V7V8 SSUrDNA) were realized. Results: Only two Galea spixii (8.1\%) and six Triatoma brasiliensis $(17.6 \%)$ were positive by hemoculture, and the isolates parasites were cryopreserved. All the isolates obtained were positioned on the Trypanosoma cruzi DTU TcI branch. Conclusions: Research focused on studying the wild animal fauna in preserved and underexplored environments has made it possible to elucidate indispensable components of different epidemiological chains of diseases with zoonotic potential.
\end{abstract}

Keywords: Trypanosoma. Marsupials. Rodents. Triatomines. Phylogeny.

\section{INTRODUCTION}

Trypanosoma cruzi belongs to the family Trypanosomatidae, order Kinetoplastida. It is a flagellate circulating in wild mammals and triatomine species of the family Reduviidae, and it is widely distributed in a variety of ecotopes covering 21 countries in the Americas ${ }^{1-11}$. This diversity of hosts in the $T$. cruzi transmission cycle has made this taxon subject to different selective pressures that have resulted in the current extreme genetic diversity ${ }^{12,13}$. Indeed, T. cruzi includes six genotypes or discrete typing units (DTUs), designated TcI to TcVI, along with TcBat, a genotype that was first described in bats, and is now considered to be a new DTU ${ }^{14-17}$.

Corresponding author: Dr. Arlei Marcili.

e-mail: amarcili@unisa.br

Received 5 May 2018

Accepted 3 July 2018
The National Park of Serra das Confusões (NPSC) is a protected area of natural landscape located in Southern Piauí, Brazil, and it is considered as one of the largest and most important protected areas in the Caatinga biome. Research focusing on trypanosome infection in wild animals and on sylvatic triatomines in preserved environments and underexplored areas has made it possible to elucidate indispensable components of different epidemiological chains of diseases with zoonotic potential. Small terrestrial mammals are an important ecological group, from the points of view of abundance and diversity of species, since they present high adaptability in different ecosystems and are considered to be reservoirs for important pathogens that can infect domestic animals and humans.

Thus, the main objective of the present study was to evaluate the infection and diversity of $T$. cruzi in wild environments in the NPSC region. Through this, support for management actions and conservation strategies within the park and epidemiological monitoring in the region can be achieved. 


\section{METHODS}

\section{Study area}

The NPSC is the largest park in Northeastern Brazil. It covers 11 municipalities in the State of Piauí, including Guaribas, Caracol, Santa Luz, Cristino Castro, Jurema, Alvorada do Gurguéia, Elizeu Martins, Canto do Buriti and Tamboril do Piauí. The NPSC comprises Caatinga and Caatinga/Cerrado areas (Figure 1).

The annual mean temperatures reach $28^{\circ} \mathrm{C} \pm 5^{\circ} \mathrm{C}$ with a maximum of $45^{\circ} \mathrm{C}$ and a minimum of $12^{\circ} \mathrm{C}$. The rainy season extends from November to April with an average rainfall of $675 \mathrm{~mm} \pm 247 \mathrm{~mm}$ and relative humidity of $80-90 \%$. In the dry season, the relative humidity is between 35 and $70 \%$. The vegetation displays typical Caatinga features and includes semideciduous forest patches ${ }^{18}$.

Sampling was concentrated during four visits to the park, in four periods: January 18 to 23 (wet and hot), May 21 to 26 (dry and hot), July 28 to August 2 (dry and hot) and October 21 to 25,2013 (dry and hot).

\section{Collection of triatomines}

Triatomines were collected from sylvatic environments (burrows, openings in the ground, bird nests, waste materials, tree trunks and stones, among others) using a selective method. This consisted of a manual search using a flashlight to inspect openings and dark places, followed by using metallic tweezers to place specimens in individual flasks labeled with information regarding the collection site.

The triatomines collected were identified using an identification $\mathrm{key}^{19}$. Natural infection of insects by trypanosomatid forms was analyzed in feces obtained by means of abdominal compression. The feces were diluted in $0.9 \%$ saline and placed between a slide and coverslip for observation under an optical microscope $\mathrm{e}^{20,21}$.

\section{Catching of small animals}

The sites for catching wild animals were chosen to cover different environments in the NPSC, such as areas of caatinga trees, caatinga shrubs, rocks, and caves, comprising seven environmental

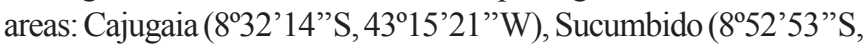

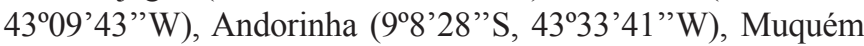

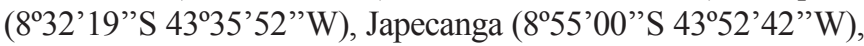
Canto Verde (8 $\left.54^{\circ} 2{ }^{\prime \prime} \mathrm{S} 43^{\circ} 27^{\prime} 27^{\prime \prime} \mathrm{W}\right)$, and Serra (9'13'34"S $\left.43^{\circ} 27^{\prime} 47^{\prime \prime} \mathrm{W}\right)$. Thus, transects were established to facilitate and monitor the fieldwork and only one time in each site.

To catch the small terrestrial mammals, we used 70 live traps (Sherman®; H.B. Sherman Traps, Tallahassee, FL, USA, and
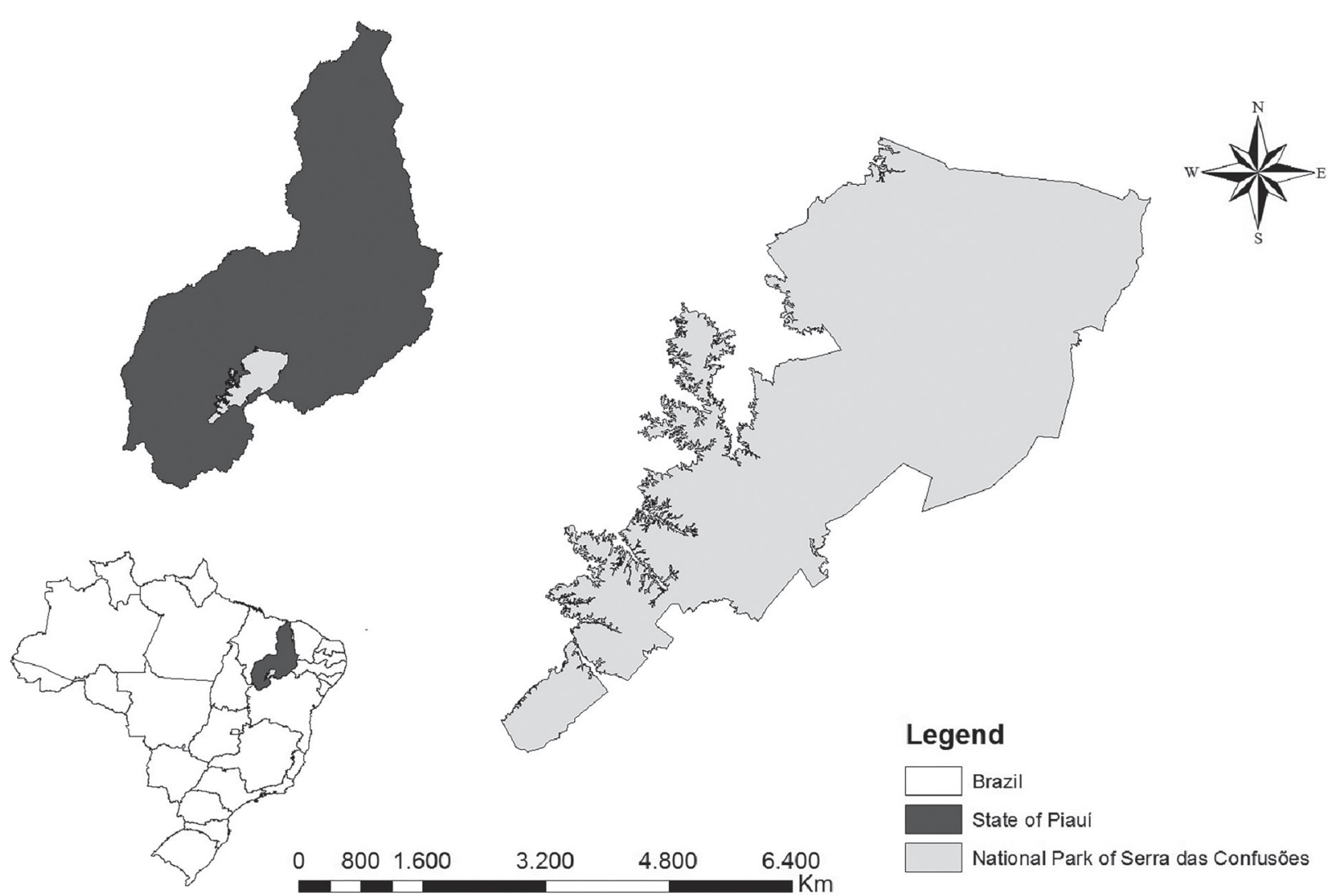

\section{Legend}

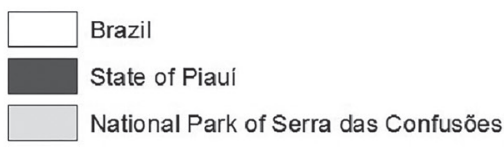

FIGURE 1: Map of Serra das Confusões. Geographical origin of isolates of Trypanosoma sp. from mammals and Triatomines caught in the National Park of Serra das Confusões, in Piauí State, Brazil. 
Tomahawk ${ }^{\circledR}$ Live Traps, Tomahawk, WI, USA) baited with a mixture of banana, peanut butter, oat, bacon, and sardines. The traps were set for five consecutive nights along random linear transects, placed on the ground at $10 \mathrm{~m}$ intervals, and alternating between trap type. They were set up one day before the field sampling and were inspected on the next morning.

Parenteral anesthesia was administered, consisting of ketamine chlorohydrate at the minimum dose appropriate for the species and weight. The general condition of each animal was determined. All animals were marked by shaving an area on the dorsum, and they were then released at the capture site once fully recovered from anesthesia. The animals were photographed, and all information relating to the capture date, geographic location, species, sex, weight, amount of anesthetic used, and morphological description were noted in the evaluation records for possible analysis during the study.

The animals were bled by means of venipuncture, and each blood sample was separated into two aliquots. One part was transferred to sterile tubes containing alcohol for polymerase chain reaction $(\mathrm{PCR})$ analysis $(500 \mu \mathrm{L})$ and the other for parasite identification in the hemoculture $(200 \mu \mathrm{L})$.

\section{Ethical considerations}

The animals were identified using identification keys and original descriptions ${ }^{22}$. The animals were caught and handled in accordance with the recommendations of the Brazilian Institute for the Environment and Renewable Natural Resources (ICMBio/SISBio, no. 36585-1). The procedures implemented were endorsed by the Ethics Committee for Animal Use of the University of São Paulo, Brazil (CEUA P-292-06), in accordance with Brazilian regulations.

\section{Culturing of Trypanosoma cruzi isolates}

To isolate trypanosomatid parasites, the blood samples obtained from wild animals and positive samples from triatomines (intestinal contents) were inoculated into Vacutainer tubes containing a biphasic medium consisting of $15 \%$ sheep red blood cells as the solid phase (blood agar base), overlain by liquid liver infusion tryptose (LIT) medium supplemented with $20 \%$ fetal bovine serum ${ }^{23-24}$. The culture was incubated at $28^{\circ} \mathrm{C}$ and grown in LIT medium for deoxyribonucleic acid (DNA) preparation. The isolates were cryopreserved in liquid nitrogen in the Brazilian Trypanosomatid Collection [Coleção Brasileira de Tripanossomatídeos (CBT)], in the Department of Preventive Veterinary Medicine and Animal Health, School of Veterinary Medicine, University of São Paulo, Brazil.

\section{Molecular characterization of Trypanosoma genotypes}

DNA was extracted from the trypanosome culture samples using the phenol-chloroform method ${ }^{25}$. Primary samples were purified using the Wizard DNA clean-up system (Promega).

The DNA samples were subjected to PCR amplification for the trypanosome barcode (V7V8 region of SSU rDNA) and Cytochrome B (CytB) as previously described ${ }^{15}$. PCR products of the expected size were purified and sequenced in an automated sequencer (ABI Prism 310). The nucleotide sequences generated were deposited in GenBank.

The newly generated sequences were aligned with sequences available in GenBank that had previously been determined for other trypanosome species, using Clustal $\mathrm{X}^{26}$. Manual adjustments were made using GeneDoc ${ }^{27}$. The alignment was used to construct phylogenetic trees using maximum parsimony, as implemented in PAUP version $4.0 \mathrm{~b} 10^{28}$ with 500 bootstrap replicates and Bayesian analysis performed using MrBayes v3.1.2 $2^{29}$ with $1,000,000$ replicates. The first $25 \%$ of the trees represented 'burn-in', and the remaining trees were used to calculate Bayesian posterior probabilities.

\section{RESULTS}

Seventy-six animals belonging to four orders, eight genera and eight species of wild mammals were caught (Table 1). Two species were caught by means of active searching: Tolypeutes

TABLE 1: Hosts species and hemoculture positivity of animals and triatomines examined in this study.

\begin{tabular}{llccc}
\hline & Hosts & & Number of individuals \\
\hline Order & Genus & Species & examined/positive & total* \\
\hline Rodentia & Thrichomys & sp & $51 / 0$ & 0 \\
& Rhipidomys & macrurus & $6 / 0$ & 2 \\
& Galea & spixii & $3 / 2$ & 0 \\
\hline Didelphimorphia & Kerodon & rupestris & $3 / 0$ & 0 \\
\hline Cingulata & Monodelphis & domestica & $9 / 2$ & 0 \\
\hline Pilosa & Gracilinanus & agilis & $2 / 2$ & 0 \\
\hline Hemiptera & Tolypeutes & tricinctus & $1 / 0$ & 0 \\
\hline Total & Tamandua & tetradactyla & $1 / 0$ & 5 \\
\hline
\end{tabular}

*Total of isolates established and cryopreserved in Coleção Brasileira de Tripanossomatídeos (CBT). 
TCC 643 [EU867803] T. rangeli

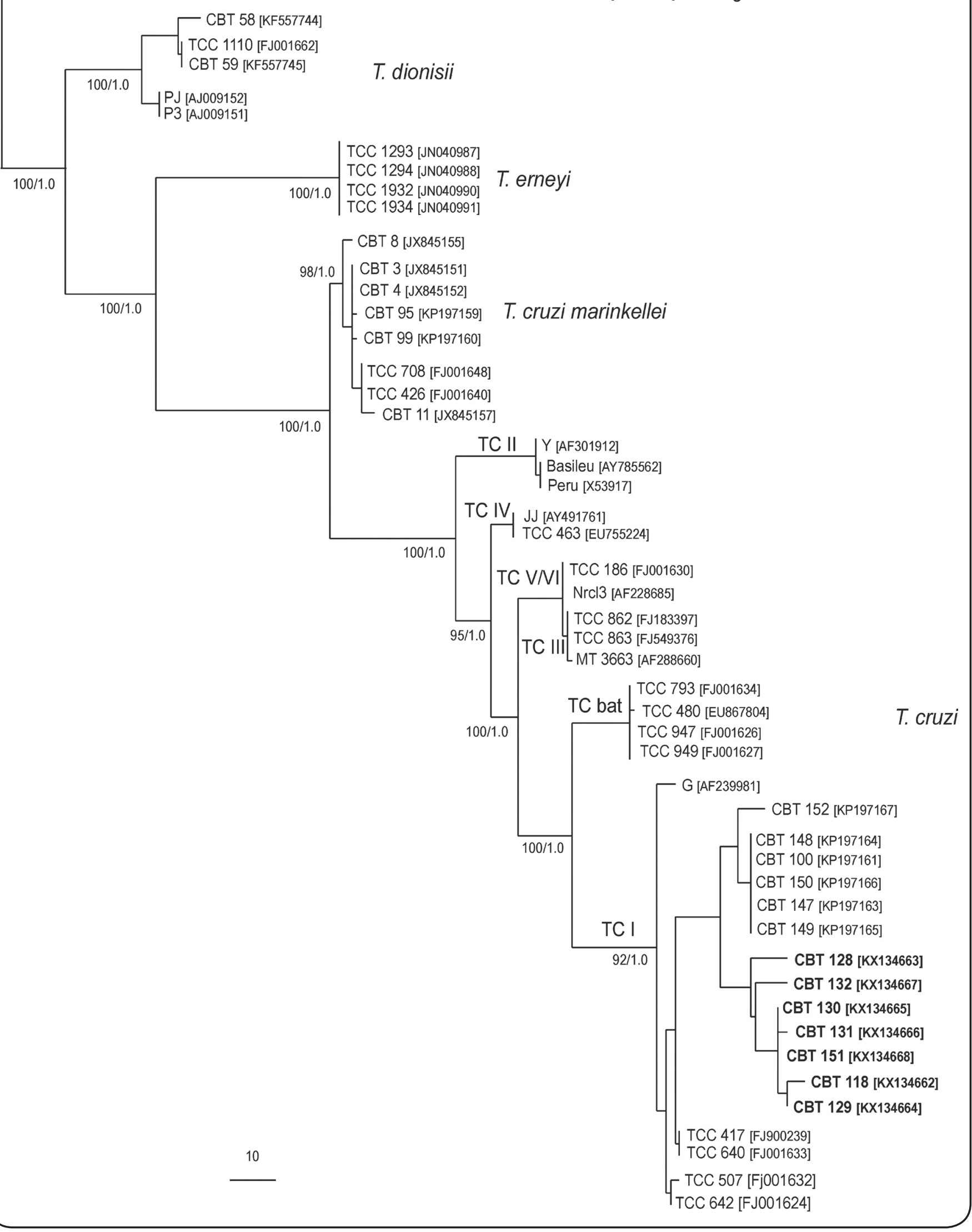

FIGURE 2: Phylogenetic tree of trypanosomes isolates from Serra das Confusões. Maximum parsimony tree inferred from SSU rDNA gene sequences of 50 trypanosomes, with Trypanosoma rangeli as the outgroup (868 characters; 181 parsimony-informative sites). Numbers at nodes are the support values for the major branches (posterior probability/bootstrap; 500 replicates). The sequences obtained in this study are underlined and in bold. CBT: Coleção Brasileira de Tripanossomatídeos. 
tricinctus and Tamandua tetradactyla. Out of the 74 animals that were caught in traps, 63 (85.1\%) were rodents and 11 (14.8\%) were marsupials.

Among all mammals caught, six hemocultures were positive (8.0\%). Only two hemocultures were isolated and cryopreserved, and the remaining four were lost. The morphology of all cultures were compatible with the subgenus Schizotrypanum.

A total of 44 specimens of insects were collected: 35 adults and nine nymphs. All specimens were identified as Triatoma brasiliensis from their morphological characteristics. Cytological identification (examination by optical microscopy to identify epimastigite or trypomastigote forms) was conducted through dissection and examination of the digestive tract to observe infection by trypanosomatids. This was done only on triatomines that arrived alive at the laboratory. Thus, out of 34 triatomines that were subjected to examination of the intestinal contents, six specimens (four adults and two nymphs) of T. brasiliensis were positive for flagellates that were morphologically similar to T. cruzi, which corresponded to a natural infection rate of $17.6 \%$. The intestinal contents of positive triatomines were inoculated into culture medium (BAB/LIT), but one culture did not grow. Five cultures obtained were cryopreserved.

The sequences of five isolates of Trypanosoma from T. brasiliensis and two isolates from Galea spixii were characterized and positioned in phylogenies based on the gene sequence SSUrDNA in T. cruzi and the TcI branch (Bootstrap $100 \% / 1.0$ posterior probability) (Figure 2). Congruent topologies were obtained through maximum parsimony and Bayesian analyses. All primary samples (blood samples) analyzed using PCR were negative.

\section{DISCUSSION}

In this study, we describe the presence of T. cruzi in triatomines and mammals that were caught in the National Park of Serra das Confusões.

Only T. brasiliensis was caught in the NPSC. The habitat of this species consists of high-temperature areas in the semi-arid region, distributed across all states of northeastern Brazil, and even in Tocantins, Goiás, and Minas Gerais ${ }^{19,30,31}$.

Its main wild ecotypes are associated with bird and mammal shelters, thus facilitating contact with animals to feeding. However, their ecological valence allows adaptation to other ecological niches, including peridomestic and home environments. This adaptive capacity makes $T$. brasiliensis a species that is capable of linking the sylvatic cycle to the domestic cycle ${ }^{32-34}$.

Therefore, the finding of infected insects in the NPSC is extremely valuable for understanding the potential risk of transmission of $T$. cruzi in this region. It is necessary to check for possible domestication of these vectors, since the park is located near precarious human habitations.

In this study, Trypanosoma sp. was found in six (8.1\%) of the 74 marsupials and rodents analyzed, with two isolate from G. spixii, popularly known as the cavy.

G. spixii is a rodent belonging to the Caviidae family, commonly found in semi-arid regions in the Caatinga and
Cerrado of Northeastern Brazil ${ }^{35}$. It has been known as a $T$. cruzi host in this Brazilian region since $1976^{36}$, and there have also been reports from the Serra da Capivara, in the state of Piauí2. T. cruzi infection in wild rodents has been described in Thrichomys laurentius in the Serra da Capivara National Park ${ }^{2}$, and in Thrichomys pachyurus and Thrichomys apereoides in the central-western region of the country ${ }^{37}$. Among marsupials, Monodelphis domestica is the one most commonly infected by $T$. cruzi, and it is considered a reservoir in Brazil and Paraguay ${ }^{16,38}$.

As shown in Serra da Capivara, the rate of natural infection of small mammals in the study area was very low compared with other biomes from Brazil and other countries in the America ${ }^{3,6,7,11,37}$, related to the diversity of vertebrate hosts and triatomines. While, a low number of isolates obtained in Caatinga can be explain by climatic seasonality, which is marked by severe drought. This probably affects the density and survival of the mammal population and, consequently, parasite transmission and its cycle ${ }^{2}$.

It should be noted that, although the parasite was not isolated in a large number of mammals, this does not mean that infection was not occurring in these animals. The absence of $T$. cruzi growth in culture medium may be explained by low levels of parasitemia, intraspecific variation between different strains, and the time that elapsed from sample collection to arrival at the laboratory ${ }^{39-42}$.

Concern regarding findings of positive animals in the park is due to the ecological and behavioral characteristics of these animals. They easily adapt to environments occupied by humans and can become reservoirs in the cycle of the T. cruzi. They may also further disperse the insects lodged in their skin, thereby facilitating propagation of the vectors ${ }^{30}$.

However, for an animal parasitized by $T$. cruzi to be considered a reservoir and have importance in maintaining the transmission cycle in a given area, factors, such as the parasite's ability to persist in the host and its interrelations with the community, need to be considered deeply ${ }^{43-45}$.

Our analysis regarding the genetic variability of parasites isolated from these vertebrate and invertebrate hosts, using the SSUrDNA gene as a molecular marker, showed that the parasites had $100 \%$ similarity with $T$. cruzi genotype I (TcI). These findings differ from the results in Serra da Capivara, where species of the genotypes TcI and TcII were found.

It needs to be borne in mind that the transmission cycle is not one-dimensional and linear, but it is a complex and unstable system formed by a complex food chain ${ }^{43}$. Thus, for prophylaxis and disease control, all links involved in the chain need to be known in order to form the basis for future measures for preventing and controlling the disease. These measures should include monitoring the health of the population in areas surrounding the NPSC, promotion of environmental education and tourism activities to raise awareness about the risk of contracting the disease, and entomological surveillance of neighboring areas with human settlements.

\section{Acknowledgments}

The authors are grateful to Dalia M. R. Machado, David P. Freire, and Nara N.V.M. Gonçalves for their valuable help during fieldwork and to the Instituto Chico Mendes de Conservação da Biodiversidade (ICMBio). 


\section{Conflict of interest}

The authors declare that there is no conflict of interest.

\section{Financial support}

Coordenação de Aperfeiçoamento de Pessoal de Nivel Superior (CAPES) and Fundação de Amparo à Pesquisa do Estado de São Paulo (FAPESP).

\section{REFERENCES}

1. Carrasco HJ, Segovia M, Llewellyn MS, Morocoima A, UrdanetaMorales S, Martínez, C, et al. Geographical distribution of Trypanosoma cruzi genotypes in venezuela. PLoS Negl Trop Dis. 2012;6(6):e1707.

2. Herrera L, D'Andrea PS, Xavier SC, Mangia RH, Fernandes O, Jansen AM. Trypanosoma cruzi infection in wild mammals of the National Park 'Serra da Capivara' and its surroundings (Piaui, Brazil), an area endemic for Chagas disease. Trans R Soc Trop Med Hyg. 2005;99(5):379-88.

3. Lisboa CV, Dietz J, Baker AJ, Russel NN, Jansen AM. Trypanosoma cruzi Infection in Leontopithecus rosalia at the Reserva Biológica de Poço das Antas, Rio de Janeiro, Brazil. Mem Inst Oswaldo Cruz. 2000;95:445-52.

4. Noireau F. Wild Triatoma infestans, a potential threat that needs to be monitored. Mem Inst Oswaldo Cruz. 2009;104(Suppl. 1):60-4.

5. Noireau F, Diosque P, Jansen AM. Trypanosoma cruzi: Adaptation to its vectors and its hosts. Vet Res. 2009;40(2):1-23.

6. Orozco MM, Enriquez GF, Alvarado-Otegui JA, Cardinal MV, Schijman AG, Kitron U, et al. New sylvatic hosts of Trypanosoma cruzi and their reservoir competence in the humid Chaco of Argentina: A longitudinal study. Am J Trop Med Hyg. 2013; 88(5):872-82.

7. Pinho AP, Cupolillo E, Mangia RH, Fernandes O, Jansen AM. Trypanosoma cruzi in the sylvatic environment: distinct transmission cycles involving two sympatric marsupials. Trans R Soc Trop Med Hyg. 2000;94(5):509-14.

8. Rocha FL, Roque ALR, de Lima JS, Cheida CC, Lemos FG, de Azevedo FC, et al. Trypanosoma cruzi Infection in Neotropical Wild Carnivores (Mammalia: Carnivora): At the Top of the T. cruzi Transmission Chain. PLoS One. 2013;8(7):e67463.

9. Roellig DM, Brown EL, Barnabé C, Tibayrenc M, Steurer FJ, Yabsley MJ. Molecular typing of Trypanosoma cruzi isolates, United States. Emerg Infect Dis. 2008;14(7):1123-5.

10. Vaz VC, D'Andrea PS, Jansen AM. Effects of habitat fragmentation on wild mammal infection by Trypanosoma cruzi. Parasitology. 2007;134(12):1785-93.

11. Yeo M, Acosta N, Llewellyn M, Sánchez H, Adamson S, Miles GAJ, et al. Origins of Chagas disease: Didelphis species are natural hosts of Trypanosoma cruzi I and armadillos hosts of Trypanosoma cruzi II, including hybrids. Int J Parasitol. 2005;35(2):225-33.

12. de Freitas JM, Augusto-Pinto L, Pimenta JR, Bastos-Rodrigues L, Gonçalves VF, Teixeira SMR, et al. Ancestral genomes, sex, and the population structure of Trypanosoma cruzi. PLoS Pathog. 2006;2(3):92-100.

13. Macedo AM, Machado CR, Oliveira RP, Pena SDJ. Trypanosoma cruzi: Genetic structure of populations and relevance of genetic variability to the pathogenesis of Chagas disease. Mem Inst Oswaldo Cruz. 2004;99(1):1-12.

14. Lima L, Espinosa-Álvarez O, Pinto CM, Cavazzana Jr M, Pavan $\mathrm{AC}$, Carranza JC, et al. New insights into the evolution of the
Trypanosoma cruzi clade provided by a new trypanosome species tightly linked to Neotropical Pteronotus bats and related to an Australian lineage of trypanosomes. Parasit Vectors. 2015;8(1):657.

15. Marcili A, Lima L, Cavazzana M, Junqueira ACV, Veludo HH, Maia da Silva F, et al. A new genotype of Trypanosoma cruzi associated with bats evidenced by phylogenetic analyses using SSU rDNA, cytochrome $\mathrm{b}$ and Histone $\mathrm{H} 2 \mathrm{~B}$ genes and genotyping based on ITS1 rDNA. Parasitology. 2009;136(6):641-55.

16. Marcili A, Lima L, Valente VC, Valente SA, Batista JS, Junqueira $\mathrm{ACV}$, et al. Comparative phylogeography of Trypanosoma cruzi TCIIc: New hosts, association with terrestrial ecotopes, and spatial clustering. Infect Genet Evol. 2009;9(6):1265-74.

17. Zingales B, Andrade SG, Briones MRS, Campbell DA, Chiari E, Fernandes O, et al. A new consensus for Trypanosoma cruzi intraspecific nomenclature: Second revision meeting recommends TcI to TcVI. Mem Inst Oswaldo Cruz. 2009;104(7):1051-54.

18. Instituto Brasileiro do Meio Ambiente e dos Recursos Naturais Renováveis (IBAMA). Plano de Manejo para o Parque Nacional da Serra das Confusões. Brasília: IBAMA; 2003. 235p. Disponível em: http://www.icmbio.gov.br/portal/images/stories/imgs-unidadescoservacao/parna_serra_das_confusoes.pdf

19. Lent H, Wygodzinsky P. Revision of the Triatominae (Hemiptera, Reduviidae), and their significance as vectors of Chagas disease. Bull Am Mus Nat Hist. 1979;163(3):127-520.

20. Guilherme AL, Pavanelli, GC, Silva SV, Costa AL, de Araújo SM. Secondary triatomine species in dwellings and other nearby structures in municipalities under epidemiological surveillance in the state of Paraná, Brazil. Rev Panam Salud Publica. 2001;9(6): 385-92.

21. Gurgel-Goncalves R. The first recorded occurrence of Psammolestes coreodes Bergroth, 1911 (Hemiptera: Reduviidae: Triatominae) in the State of Mato Grosso do Sul, Brazil. Rev Soc Bras Med Trop. 2010;43(1):105.

22. Bonvicino CR, Gonalves PR, De Oliveira JA, De Oliveira LFB, Mattevi MS. Divergence in zygodontomys (Rodentia: Sigmodontinae) and distribution of Amazonian Savannas. J Hered. 2009;100(3):322-8.

23. Marcili A, da Costa AP, Soares HS, Acosta ICL, de Lima JTR, Minervino AHH, et al. Isolation and Phylogenetic Relationships of Bat Trypanosomes from Different Biomes in Mato Grosso, Brazil. J Parasitol. 2013;99(6):1071-6.

24. Marcili A, Sperança MA, da Costa AP, Madeira MF, Soares H.S, Sanches COCC, et al. Phylogenetic relationships of Leishmania species based on trypanosomatid barcode (SSU rDNA) and gGAPDH genes: Taxonomic revision of Leishmania (L.) infantum chagasi in South America. Infect Genet Evol. 2014;25:44-51.

25. Sambrook J, Fritsch EF, Maniatis T. Molecular cloning: a laboratory manual. $2^{\text {nd }}$ edition. New York- USA: Gold Spring Harbor Laboratory Press; 1989. 426p.

26. Thompson JD, Gibson TJ, Plewniak F, Jeanmougin F, Higgins DG. The CLUSTAL X windows interface: flexible strategies for multiple sequence alignment aided by quality analysis tools. Nucleic Acids Res. 1997;25(24):4876-82.

27. Nicholas KB, Nicholas HB, Deerfield DW. Analysis and visualization of genetic variation. Embnet News. 1997;4:14.

28. Swofford DL. PAUP: Phylogenetic analysis using parsimony (and other methods). Version 4.0b10. Sunderland, Massachusetts, USA: Sinauer and Associates; 2002.

29. Huelsenbeck JP. Bayesian inference of phylogeny and its impact on evolutionary biology. Science. 2001;294(5550):2310-4. 
30. Forattini OP. Biogeography, origin and distribution of triatominae domicile dispersal in Brazil. Rev Saude Publica. 1980;14(265):99.

31. Silveira AC, Feitosa V, Borges R. Distribution of Triatominae captured in a domestic environment, 1975/83, Brazil. Rev Bras Malariol Doenças Trop. 1984;36:15-312.

32. Bezerra CM, de Góes Cavalcanti LP, de Souza RCM, Barbosa SE, Xavier SCC, Jansen, AM, et al. Domestic, Peridomestic and wild hosts in the transmission of Trypanosoma cruzi in the Caatinga area colonised by Triatoma Brasiliensis. Mem Inst Oswaldo Cruz. 2014;109(7):887-98.

33. Lorenzo MG, Guarneri AA, Pires HH, Diotaiuti L, Lazzari CR. Microclimatic properties of the Triatoma brasiliensis habitat. Cad saude publica. 2000;16(Suppl 2):69-74.

34. Vitta ACR, Mota TRP, Diotaiuti L, Lorenzo MG. The use of aggregation signals by Triatoma brasiliensis (Heteroptera: Reduviidae). Acta Trop. 2007;101(2):147-52.

35. Santos PRS, Carrara TVB, Silva LCS, Silva AR, Oliveira MF, Assis Neto AC. Caracterização morfológica e frequência dos estádios do ciclo do epitélio seminífero em preás (Galea spixii Wagler, 1831) criados em cativeiro. Pesqui Vet Bras. 2011;31(Suppl. 1):18-24.

36. Alencar AA, Brito C, Azevedo B. Involvement of the male genital apparatus in Chagas' disease. Experimental study with albino mice (possibility of transmission of the disease through the semen). Mem Inst Oswaldo Cruz. 1987;82:59.

37. Xavier SCC, Vaz VC, D'Andrea PS, Herrera L, Emperaire L, Alves JR, et al. Mapping of the distribution of Trypanosoma cruzi infection among small wild mammals in a conservation unit and its surroundings (Northeast-Brazil). Parasitol Int. 2007;56(2):119-28.
38. Bern C, Kjos S, Yabsley MJ, Montgomery SP. Trypanosoma cruzi and chagas' disease in the united states. Clin Microbiol Rev. 2011;24(4):655-81.

39. Brener Z, Chiari E 1965. Aspects of early growth of different Trypanosoma cruzi strains in culture medium. [J Parasitol. 1965;51(6):922-6.

40. Chiari E. Growth and differentiation of Trypanosoma cruzi culture forms kept in laboratory for different periods of time. Rev Inst Med Trop Sao Paulo. 1974;16(2):81-7.

41. Lisboa CV, Pinho AP, Monteiro RV, Jansen AM. Trypanosoma cruzi (kinetoplastida Trypanosomatidae): Biological heterogeneity in the isolates derived from wild hosts. Exp Parasitol. 2007;116(2):150-55.

42. Mello DA. Population studies of some species of rodents (north of Formosa, Goias). Rev Bras Biol. 1980;40:843-60.

43. Jansen AM, Roque ALR. Domestic and Wild Mammalian Reservoirs. In: Telleria J, Tibyarenc M, editors. American Trypanosomiasis - Chagas Disease, $1^{\text {st }}$ edition. London: Elsevier; 2010. p. 249-76.

44. Roque ALR, Cupolillo E, Marchevsky RS, Jansen AM. Thrichomys laurentius (rodentia; echimyidae) as a putative reservoir of Leishmania infantum and L. braziliensis: Patterns of experimental infection. PLoS Negl Trop Dis. 2010;4(2):e589.

45. Roque ALR, Xavier SCC, Rocha MG, Duarte ACM, Andrea PSD, Jansen AM. Trypanosoma cruzi transmission cycle among wild and domestic mammals in three areas of orally transmitted Chagas Disease outbreaks. Am J Trop Med Hyg. 2008;79(5):742-9. 